\title{
Potensi Bawang Putih (Alium Sativum) dan Lactobacillus achidophilus sebagai Sinbiotik terhadap Kadar Kalsium, Protein serta Masa Kalsium, Protein Daging Ayam Broiler
}

\author{
The Effect of Garlic (Alium stivum) And Lactobacillus aidophilus as Synbiotics For Calcium, \\ Protein Levels and Calcium, Protein Mass of Broiler Chicken Meat
}

\author{
H. J. Indraeni, L. D. Mahfudz* dan D. Sunarti \\ Faculty of Animal and Agriculture Sciences, Diponegoro University, \\ Tembalang Campus, Semarang 50275 - Indonesia \\ * Corresponding e-mail : 1mahfudz@gmail.com
}

\begin{abstract}
This study was aimed to examine the effect of garlic (Alium sativum) and Lactobacillus acidophilus as synbiotics for calcium, protein levels and calcium, protein mass of broiler chicken meat. Experiments used 144 DOC 7-dayold Cobb strains CP 707 unsexed with body weights of $218.5 \pm 8.87 \mathrm{~g}$, with completely design (CRD) with 3 treatments and 8 replications and each unit consist of 6 birds. The treatments given were T0: basal ration; T1: basal ration $+2 \mathrm{ml}$ synbiotic; $\mathrm{T} 2$ : basal ration $+4 \mathrm{ml}$ synbiotic. The parameters measured including the calcium, protein levels and calcium, protein mass broiler of meat. The research data were analyzed using analysis of variance with the $\mathrm{F}$ test to know the effect of treatment. If there were significant effect of treatment, continous to Duncan's multiple range test, with the help of a statistical analysis system (SAS). The results showed that sinbiotik from garlic extract and Lactobacillus acidophilus supplementation the ration with a level of $2 \mathrm{ml} / 1 \mathrm{~kg}$ was able to increase the protein mass and $4 \mathrm{ml} / 1 \mathrm{~kg}$ was able to increase the level of meat protein of broiler meat was not able to increase the calcium levels and calcium mass.
\end{abstract}

Key words: synbiotic, broiler chicken, Lactobacillus achidophillus, garlic

\begin{abstract}
ABSTRAK
Tujuan dari penelitian ini yaitu mengkaji pengaruh bawang putih (Alium sativum) dan Lactobacillus acidophilus sebagai sinbiotik terhadap kadar kalsium, protein serta masa kalsium, protein daging ayam broiler. Percobaan menggunakan 144 ekor DOC umur 7 hari strain Cobb dengan merk dagang CP 707 unsexed dengan bobot 218,5 $\pm 8,87 \mathrm{~g}$, digunakan rancangan acak lengkap (RAL) dengan 3 perlakuan dan 8 ulangan setiap unit percobaan terdiri dari 6 ekor. Perlakuan yang diberikan yaitu T0 : ransum basal; T1 : ransum basal $+2 \mathrm{ml}$ sinbiotik; T2 : ransum basal $+4 \mathrm{ml}$ sinbiotik. Parameter yang diukur yaitu kadar kalsium, masa kalsium serta kadar kalsium protein daging. Data hasil penelitian dianalisis menggunakan analisis ragam dengan uji $\mathrm{F}$, apabila terdapat pengaruh perlakuan yang nyata dilanjutkan dengan uji beda wilayah ganda Duncan, dengan bantuan statistical analysis system (SAS). Hasil penelitian menunjukkan bahwa penambahan sinbiotik ekstrak bawang putih dan Lactobacillus acidophilus dalam ransum dengan level $2 \mathrm{ml} / 1 \mathrm{~kg}$ ransum mampu meningkatkan masa protein daging serta penambahan sinbotik $4 \mathrm{ml} / 1 \mathrm{~kg}$ ransum mampu meningkatkan kadar protein daging namun belum mampu meningkatkan kadar serta massa kalsium daging.
\end{abstract}

Kata kunci: sinbiotik, ayam broiler, Lactobacillus achidophillus, bawang putih

\section{PENDAHULUAN}

Ayam broiler merupakan ayam tipe pedaging yang dihasilkan dari seleksi genetik sehingga dapat mencapai bobot badan tertentu dalam waktu singkat. Namun, ayam broiler memiliki daya tahan tubuh yang rendah sehingga peternak menggunakan antibiotic growth promotor (AGP) untuk meningkatkan daya tahan dan memacu pertumbuhan ayam broiler. Penggunaan AGP secara terus - menerus pada ayam broiler dapat menyebabkan ayam broiler resisten terhadap antibiotik serta dapat meninggalkan residu pada karkas dan kotoran ayam broiler, sehingga membahayakan manusia yang mengkonsumsi serta pencemaran lingkungan. Melihat kondisi tersebut pemerintah mengeluarkan kebijakan pelarangan penggunaan antibiotik untuk ternak. Oleh karena itu, dicari perlu alternatif dengan memanfaatkan feed aditif seperti prebiotik, probiotik serta kombinasi probiotik dan prebiotik mejadi sinbiotik 
Bawang putih diduga juga dapat mengoptimalkan fungsi metabolisme sehingga dapat meningkatkan efisiensi penggunaan pakan. Bawang putih mengandung frukto oligosakarida (FOS) sebanyak 3,34\% sehingga dapat digunakan sebagai prebiotik. Diketahui bahwa FOS merupakan senyawa karbohidrat rantai sedang yang dikenal sebagai prebiotik sehingga dapat menjadi nutrisi bagi probiotik. Bawang putih dapat digunakan sebagai nutrisi bagi Lactobacillus acidophilus karena bakteri ini tahan terhadap allicin yang terdapat pada bawang putih sehingga Lactobacillus acidophilus dapat dijadikan probiotik yang baik apabila dikombinasikan dengan bawang putih.

Sinbiotik adalah gabungan antara prebiotik (bawang putih) serta probiotik (Lactobacillus acidophilus). Bawang putih menjadi sumber nutrisi bagi Lactobacillus acidophilus sehingga dapat meningkatkan populasi BAL dan menurunkan $\mathrm{pH}$, sehingga kondisi $\mathrm{pH}$ di dalam usus semakin asam. Kondisi saluran pencernaan yang asam akan memproduksi SCFA (Short Chain Fatty Acid) sehingga dapat menekan populasi bakteri pathogen seperti $E$. coli.

Enzim pencernaan berperan dalam proses hidrolisis nutrient seperti molekul protein, lemak serta karbohidrat pakan menjadi lebih sederhana, sehingga kecernaan pakan menjadi meningkat. Kecernaan protein yang meningkat menyebabkan peningkatan asupan protein yang digunakan untuk mensintesis protein. Meningkatnya protein yang disintesis dibanding dengan protein yang didegradasi menyebabkan meningkat pula massa protein daging. Peningkatan massa protein daging erat hubungannya dengan produktivitas atau pertambahan bobot badan. Kalsium yang diserap oleh tubuh akan disimpan ke dalam tulang sebanyak $98 \%$ dan ke dalam cairan ekstra seluler sebanyak 2\%. Penyerapan kalsium bersamaan dengan penyerapan protein melaui mekanisme calsium binding protein $(\mathrm{CaBP})$. Kalsium yang terikat dengan protein akan membantu proses pembentukan protein, akibatnya kalsium dalam bentuk ion bebas rendah. Walaupun kadar protein meningkat namun belum mampu meningkatkan kadar kalsium daging serta masa kalsium daging. Tujuan dari penelitian ini yaitu mengkaji pengaruh bawang putih (Alium sativum) dan Lactobacillus acidophilus sebagai sinbiotik terhadap kadar kalsium, protein serta masa kalsium, protein daging ayam broiler.

\section{MATERI DAN METODE}

Materi yang digunakan dalam penelitian ini yaitu ternak sebanyak 144 ekor DOC umur 7 hari strain Cobbun sexed dengan bobot badan $218,5 \pm 8,87 \mathrm{~g}$, dibagi dalam 3 perlakuan dan 8 ulangan, setiap unit percobaan terdapat 6 ekor. Bahan yang digunakan dalam penelitan ini yaitu ransum yang terdiri (jagung, dedak, bungkil kedelai, tepung ikan, premix), sinbiotik yang tersusun dari ekstrak bawang putih dan Lactobacillus acidophilus.

Rancangan penelitian yang digunakan adalah rancangan acak lengkap (RAL) yang terdiri dari 3 perlakuan dan 8 ulangan. Ransum yang digunakan yaitu:

T0 $=$ Ransum basal

$\mathrm{T} 1=$ Ransum basal $+2 \mathrm{ml}$ sinbiotik

$\mathrm{T} 2=$ Ransum basal $+4 \mathrm{ml}$ sinbiotik

Data hasil penelitian dianalisis menggunakan analisis ragam dengan uji $\mathrm{F}$, apabila terdapat pengaruh perlakuan yang nyata dilanjutkan dengan uji beda wilayah ganda Duncan (Steel and Torrie, 1991).

Tahap pembuatan sinbiotik yaitu terlebih dahulu membuat ekstrak bawang putih. Bawang putih dikupas kulitnya kemudian di cuci dan diiris dengan ketebalan $\pm 1 \mathrm{~cm}$. Potongan tersebut dimasukkan ke dalam juicer untuk diambil ekstraknya. Ekstrak bawang putih kemudian disaring dan disterilkan dengan metode pasteurisasi selama 10 menit. Ekstrak bawang putih diletakkan pada wadah dan di simpan di tempat tertutup suhu dibawah $20^{\circ} \mathrm{C}$. Jumlah ekstrak bawang putih yang terbaik diperoleh $2 \mathrm{ml}$ dan $4 \mathrm{ml}$. Ekstrak bawang putih $100 \mathrm{ml}$ dicampurkan dengan Lactobacillus acidophilus 1 $\mathrm{ml}$. Isolat yang digunakan yaitu dari Media Rogosa dan Sharpe (MRS) gliserol 20\%, kultur bakteri diremajakan pada media MRS Agar diinkubasi pada suhu $37^{\circ} \mathrm{C}$ selama 24 - 48 jam untuk mengaktifkan bakteri kemudian diinokulasi ke dalam MRS broth sebanyak 1 oose dan diinkubasi pada suhu $37^{\circ} \mathrm{C}$ selama 24 jam.

Tahap awal yang dilakukan yaitu sanitasi dalam serta sanitasi luar kandang. Membuat brooder serta pembuatan plot kandang, pencucian kandang serta peralatan kandang, pengapuran lantai dan dinding kandang fumigasi. Memasang lampu pada booder serta memasang litter, tirai kandang ditutup dengan rapat. 
Tabel 1. Komposisi dan kandungan nutrien ransum ayam broiler

\begin{tabular}{lc}
\hline \multicolumn{1}{c}{ Bahan Pakan } & Komposisi Ransum \\
\hline Jagung & $-------(\%)--------$ \\
Dedak & 51,50 \\
Bungkil Kedelai & 15,00 \\
Tepung Ikan & 23,00 \\
Premiks & 10,00 \\
\hline Total & 5,0 \\
\hline EM (kkal/kg) & 100,00 \\
PK (\%) & $3.051,00$ \\
LK (\%) & 22,01 \\
SK (\%) & 6,20 \\
Ca (\%) & 4,36 \\
P (\%) & 1,99 \\
Arginin (\%) & 1,08 \\
Methionin (\%) & 1,29 \\
Lisin (\%) & 0,49 \\
Keterangan: Bahan pakan dianalisis di Laboratorium \\
\multicolumn{2}{c}{ Ilmu Nutrisi dan Pakan Fakultas } \\
\multicolumn{2}{c}{ Peternakan dan Pertanian, Universitas } \\
\multicolumn{1}{c}{ Diponegoro, Semarang (2019). }
\end{tabular}

Day old chick (DOC) selama satu minggu dipelihara di dalam brooder untuk proses adaptasi selanjutnya dibagi berdasarkan bobot yang seragam dan dimasukkan ke dalam kandang yang sesuai dengan perlakuan. Perlakuan yang dilakukan pada ayam umur 1-7 hari diberi pakan komersial BR I dan air minum secara ad libitum. Pada umur 7-42 ayam diberi ransum dan tambahan sinbiotik dan air minum diberikan secara ad libitum. Pemeliharaan dilakukan selama 6 minggu.

Tahap pengambilan data yang dilakukan pada umur 42 hari yaitu memotong ayam dan mengambil sampel daging untuk di analisis kadar kalsium dan protein serta menghitung masa kalsium dan protein daging ayam broiler. Menurut Prabowo et al., (2019) kadar kalsium dan protein daging diperoleh dengan cara menganalisis sampel yang diambil dari daging tanpa kulit bagian dada dan paha kemudian daging dicampur dan digiling halus kemudian diambil sampel untuk dianalisis kadar kalsium dan protein. Masa kalsium dan protein daging dihitung berdasarkan Suthama (2003) sebagai berikut.

Masa Kalsium Daging = \% kadar kalsium daging $\mathrm{x}$ bobot daging $(\mathrm{g})$

Masa protein daging $=\%$ kadar protein daging $\mathrm{x}$ bobot daging $(\mathrm{g})$

\section{HASIL DAN PEMBAHASAN}

Berikut hasil penelitian kadar kalsium serta protein dan masa kalsium serta protein daging ayam broiler akibat penambahan sinbiotik dari ekstrak bawang putih dengan Lactobacillus acidophilus dalam pakan.

\section{Kadar Kalsium Daging}

Berdasarkan hasil perhitungan statistik penambahan sinbiotik dari ekstrak bawang putih dan Lactobacillus acidophillus pada ransum terhadap kadar kalsium daging ayam (Tabel 2) belum mampu meningkatkan secara nyata $(\mathrm{P}>0,05)$. Penambahan sinbiotik ke dalam ransum dapat meningkatkan BAL dalam saluran pencernaan. Mikroba BAL berperan dalam menfermentasi karbohidrat kemudian menghasilkan short chain fatty acid (SCFA) yang mengoptimalkan kerja saluran pencernaan. Saluran pencernaan yang bekerja secara optimal mengakibatkan penyerapan nutrien seperti kalsium dan menjadi lebih optimal pula. Scott et al., (1982) menyatakan bahwa protein berperan dalam proses pengangkutan kalsium; kalsium yang terkandung di dalam ransum diserap dalam usus halus pada proses deposisi protein. Proses penyerapan kalsium dipengaruhi oleh protein yang disebut dengan CaBP. Mentari et al. (2019) menyatakan bahwa penyerapan kalsium bersamasama dengan penyerapan protein melalui mekanisme calsium binding protein (CaBP). Kalsium masuk ke pembuluh darah kemudian

Tabel 2. Kadar kalsium, masa kalsium daging dan kadar protein, masa protein daging

\begin{tabular}{lrrr}
\hline \multirow{2}{*}{ Parameter } & \multicolumn{3}{c}{ Perlakuan } \\
\cline { 2 - 4 } & $\mathrm{T} 0$ & $\mathrm{~T} 1$ & $\mathrm{~T} 2$ \\
\hline Kadar kalsium (\%) & 0.05 & 0.05 & 0.04 \\
Kadar protein (\%) & $17.95^{\mathrm{b}}$ & $18.87^{\mathrm{b}}$ & $20.12^{\mathrm{a}}$ \\
Masa kalsium (g) & 0.23 & 0.27 & 0.26 \\
Masa protein (g) & $73.97^{\mathrm{b}}$ & $114.53^{\mathrm{a}}$ & $132.71^{\mathrm{a}}$ \\
\hline
\end{tabular}

Keterangan: Superskrip dengan huruf yang berbeda pada baris yang sama menunjukkan perbedaan nyata $(\mathrm{P}<0,05)$ 
diangkut ke jaringan yang membutuhkan (tulang dan daging). Kalsium yang terikat dengan protein menyebabkan kalsium dalam bentuk ion bebas dalam daging rendah. Sehingga meningkatnya kadar protein daging tidak dibarengi dengan peningkatan kadar kalsium, akibatnya kadar kalsium dengan penambahan simbiotik tidak berbeda nyata.

Kalsium akan lebih banyak disimpan ke dalam tulang disbanding ke dalam daging. Murwani (2010) menyatakan bahwa kalsium yang diserap oleh tubuh akan disimpan ke dalam tulang sebanyak 98\% serta ke dalam cairan ekskreta seluler sebanyak $2 \%$. Kalsium bebas yang ada di seluler sedikit, sehingga penambahan simbiotik belum mampu meningkatkan kadar kalsium dalam daging ayam broiler.

\section{Kadar Protein Daging}

Berdasarkan hasil perhitungan statistik perlakuan penambahan sinbiotik dari ekstrak bawang putih dan Lactobacillus acidophilus mampu meningkatkan secara nyata $(\mathrm{P}<0,05)$ terhadap kadar protein daging (Tabel 2). Hal ini disebabkan oleh sinbiotik di dalam saluran pencernaan akan meningkatkan jumlah BAL. Mikroba BAL berperan dalam memfermentasi karbohidrat dan menghasilkan SCFA yang mengoptimalkan kerja saluran pencernaan. Nagara et al. (2019) menyatakan bahwa SCFA dan asam laktat yang tinggi akan menurunkan $\mathrm{pH}$ usus sehingga menekan bakteri pathogen sehingga menyebabkan saluran pencernaan lebih sehat. Lactobacillus merupakan bakteri yang dapat menghasilkan bakteriosin yang bersifat antagonis terhadap bakteri pathogen. $\mathrm{pH}$ saluran pencernaan yang rendah (asam) akan mengaktifkan enzim enzim perncernaan (kasein-fosfatasekaseinfosfatase), vitamin-vitamin (B-kompleks).

Enzim pencernaan ini berperan dalam proses hidrolisis nutrient pakan menjadi lebih sederhana, seperti memisahkan molekul protein, lemak serta karbohidrat sehingga kecernaan pakan akan meningkat. Mahfudz (2006) menyatakan bahwa kecernaan pakan yang meningkat dapat memicu proses penyerapan nutrien khususnya protein. Penyerapan protein yang optimal dapat meningkatkan kadar protein dalam daging. Nagara et al. (2019) menyatakan bahwa penyerapan yang meningkat sehingga kadar protein dalam daging juga tinggi. Hal tersebut dapat dilihat dari meningkatnya kadar protein daging ayam broiler yang diberi sinbiotik dalam ransum.

\section{Masa Kalsium Daging}

Berdasarkan hasil perhitungan statistic penambahan sinbiotik dari ekstrak bawang putih dan Lactobacillus acidophillus pada ransum terhadap masa kalsium daging ayam (Tabel 2) belum mampu meningkatkan secara nyata $(\mathrm{P}>0,05)$. Scott et al. (1982) menyatakan bahwa protein berperan dalam proses pengangkutan kalsium, kalsium yang terkandung di dalam ransum akan diserap oleh usus halus pada proses deposisi protein, kemudian masuk ke pembuluh darah dan diangkut ke jaringan yang membutuhkan yaitu tulang dan daging. Kalsium dan protein penyerapannya bersamaan melaui mekanisme $\mathrm{CaBP}$ tetapi ion kalsium terikat dengan protein pada proses sintesis protein, akibatnya kalsium dalam bentuk ion bebas rendah. Walaupun penambahan sinbiotik meningkatkan kadar protein namun belum mampu meningkatkan kadar kalsium daging serta masa kalsium daging.

Kalsium akan lebih banyak disimpan di dalam tulang dibandingkan di dalam daging. Murwani (2010) menyatakan bahwa kalsium yang diserap oleh tubuh akan disimpan ke dalam tulang sebanyak $98 \%$ serta ke dalam cairan ekstra seluler sebanyak 2\%. Rendahnya ion kalsium dalam daging dan sedikitnya kalsium ektra selular (2\%) menyebakan kadar serta masa kalsium tidak berbeda nyata walau sudah diberikan sinbiotik di dalam ransum.

\section{Masa Protein Daging}

Berdasarkan hasil perhitungan statistik perlakuan penambahan sinbiotik dari ekstrak bawang putih dan Lactobacillus acidophilus mampu meningkatkan secara nyata $(\mathrm{P}<0,05)$ terhadap masa protein daging (Tabel 2). Hal ini disebabkan karena pemberian sinbiotik dalam ransum memberikan keuntungan pada saluran percernaan. Pemberian sinbiotik pada ransum ayam akan meningkatkan BAL pada saluran pencernaan sehingga saluran pencernaan menjadi lebih sehat dan penyerapan nutrien seperti protein menjadi optimal. Sari et al. (2019) menyatakan bahwa pemberian sinbiotik dalam ransum mampu meningkatkan jumlah BAL dan menurunkan $\mathrm{pH}$ dalam saluran pencernaan sehingga kecernaan serta penyerapan protein meningkat.

Ketersediaan protein sebagai substrat berhubungan erat dengan metabolisme protein khususnya proses deposisi protein. Penyerapan protein yang meningkat akan menyebabkan protein yang dimanfaatkan dalam daging menjadi optimal sehingga meningkatkan deposisi protein ke dalam daging. Deposisi protein dalam daging 
akan meningkatkan masa protein di dalam daging. Nagara et al. (2019) menyatakan bahwa peningkatan deposisi protein akan mempengaruhi peningkatan masa protein daging. Hal tersebut dapat dilihat dari meningkatnya masa protein daging ayam broiler yang diberi sinbiotik dalam ransum.

\section{KESIMPULAN}

Berdasarkan hasil penelitian, dapat disimpulkan penambahan sinbiotik ekstrak bawang putih dan Lactobacillus acidophilus dalam ransum dengan level $2 \mathrm{ml} / 1 \mathrm{~kg}$ ransum mampu meningkatkan masa protein daging serta penambahan sinbotik $4 \mathrm{ml} / 1 \mathrm{~kg}$ ransum mampu meningkatkan kadar protein daging namun belum mampu meningkatkan kadar serta masa kalsium daging. Penambahan sinbiotik ekstrak bawang putih dan Lactobacillus acidophilus sebaiknya sebesar $4 \mathrm{ml} / 1 \quad \mathrm{~kg}$ ransum karena mampu meningkatkan kadar dan massa protein daging.

\section{DAFTAR PUSTAKA}

Brikisma, S. H. L., L. D. Mahfudz dan N. Suthama. 2014. Kemampuan produksi ayam broiler yang diberi tepung jambu biji merah sebagai sumber antioksidan alami. J. Ilmu dan Teknologi Peternakan 3(2): 69-75.

Jamilah., N. Suthama, dan L. D. Mahfudz. 2013. Performa produksi dan ketahanan tubuh broiler yang diberi pakan step down dengan penambahan asam sitrat sebagai $\begin{array}{ll}\text { acidifier. JITV. } 18 & \text { (4): 251-257. }\end{array}$

Mahfudz, L. D. 2006. Ampas tahu fermentasi sebagai bahan pakan ayam pedaging. J. Caraka Tani 21 (1): 39-43.

Mentari A.S., L. D. Mahfudz dan N. Suthama. 2014. Massa protein dan lemak daging pada ayam broiler yang diberi tepung temukunci (Boesenbergia pandurata Roxb.) dalam ransum. J. Animal Agriculture 3(2): 211220.

Murwani, R. 2010. Broiler modern. Widya Karya, Semarang.

Nagara, R. L. K., S. Kismiati, S. Setyaningrum, dan L. D. Mahfudz. 2019. Masa protein dan kalsium daging ayam broiler akibat penambahan sinbiotik dalamransum. J. Peternakan Indonesia 21 (3): 198-204.

Prabowo, L, D. Mahfudz, dan U. Atmomarsono. 2019. masa kalsium dan massa protein daging akibat penggunaan tepung limbahwortel (Daucus carota 1) dalam ransum ayam broiler. Jurnal Sain Peternakan Indonesia 14 (2): 201-207.

Sari, D. R., E. Suprijatna, S. Setyaningrum, dan L. D. Mahfudz. 2019. Suplementasi inulin umbi gembili dengan Lactobacillus plantarum (sinbiotik) terhadap nisbah daging-tulang ayam broiler. Jurnal Peternakan Indonesia 21 (3): 284-293.

Scott, M. L., M. C. Nesheim, and R. J. Young. 1982. Nutrition of the Chicken Edition M. L. Scott Associate. Ithaca, New York.

Steel, C. J. dan J. H. Torrie. 1991. Prinsip dan prosedur statistik. Gramedia, Jakarta.

Suthama, N. 2003. Metabolisme protein pada ayam kampong periode partumbuhan yang diberi ransum memakai dedak padi fermentasi. J. Pengemb. Pet. Trop. Edisi Spesial : 44-48.

Syafitri, Y. E., V. D. Yunianto dan N. Suthama. 2015. Pemberian ekstrak daun beluntas (Pluchea indica Less) dan klorin terhadap masa kalsium dan masa protein daging ayam broiler. J. Anim. Agri. 4 (1): 155-164. 